J. Amer. Soc. Hort. ScI. 120(5):843-847. 1995.

\title{
White-mold Avoidance and Agronomic Attributes of Upright Common Beans Grown at Multiple Planting Densities in Narrow Rows
}

\author{
Gilles Saindon, Henry C. Huang, and Gerry C. Kozub \\ Research Centre, Agriculture and Agri-Food Canada, Lethbridge, AB, T1J 4B1, Canada
}

\begin{abstract}
Additional index words. common beans, Phaseolus vulgaris, Sclerotinia sclerotiorum, white mould, growth habit, canopy architecture, planting density

Abstract. The putative yield advantage associated with growing upright beans (Phaseohs vulgaris L.) at high planting densities in narrow (0.23-m) rows might he compromised by a higher risk of white mold [Sclerotinia sclerotiorum (Lib.) de Bary] because of reduced air flow through the crop canopy. This four-yeai-study was undertaken to compare the whitemold avoidance and agronomic attributes of upright bean lines and to determine whether their yields can he increased by raising planting density. Four upright lines and a viny line as a control were established in narrow rows at planting densities ranging from 25 to 60 plants/m* in a field artificially infested with sclerotia of $S$. sclerotiorum. On average, the four upright lines had lower incidence of white mold and smaller disease severity indices than the control, 'UI36', indicating that the development of white mold is reduced in dense, erect canopies. There were differences in disease response among the upright lines, with 'ISB82865' and 'UI906' being the least and most susceptible entries, respectively. Increases in planting densities resulted in higher yields and influenced the development of white mold hut had no effect on vine length, lodging, and maturity. However, the planting density effect on the disease response was not consistent among entries in 2 of the 4 years. The results of this study indicate that upright beans can he grown at high planting densities without greatly increasing the risk of a white-mold outbreak. The choice of the most appropriate planting density for upright beans depends largely on the cost of seed.
\end{abstract}

Commercial production of common beans in western Canada is centered in the irrigated districts of southern Alberta and in the dryland region of southern Manitoba. The high-yielding cultivars used by western Canada producers are viny in growth habit and produce dense, prostrate canopies. Insufficient aeration, high humidity, and prolonged periods of dampness often associated with those canopies favor the development of white mold, the most economically important disease of common beans in western Canada (Huang et al., 1988).

Coyne et al. (1974) proposed that white mold could be controlled by growing upright beans in wide (0.6- to $0.7-\mathrm{m})$ rows. Upright beans are erect, have a few branches, and produce a narrow crop canopy that decreases the incidence of white mold by preventing contact of leaves and pods with the soil and permitting greater air flow through the canopy. However, yields of upright beans grown at conventional planting densities $\left(1.5\right.$ to 25 plants $\left./ \mathrm{m}^{2}\right)$ in wide rows may not be maximized, as the crop canopy does not always achieve full ground coverage. Indeed, in soybean [Glycine ma.x (L.) Merr.], yields were maximized when complete solar interception was attained before flowering (Shibles and Weber, 1966). Saindon et al. (1993a) showed that yields of LRS92-1, an upright navy bean germplasm line (Saindon et al., 1993b), increased when row spacing was reduced to 0.3 from $0.6 \mathrm{~m}$. Park (1993) found that the seed yield of upright beans increased as row width decreased. Lastly, seed or pod yields of beans rise as plant population density increases (Field and Nkumbula, 1986; Mack and varseveld, 1982; Mack, 1983; Mauk et al., 1983; Redden et al., 1987; Tripathi and Singh, 1986; Wahab et al., 1986).

Received for publication 27 Sept. 1994. Accepted for publication 21 Mar. 1995. This paper is Lethbridge Research Centre contribution 3879476. We thank M.T. Mueller, R.S. Erickson, C.A. Mueller, C. Daniels, G. Bohus, and L.M. Phillippe for technical assistance and B.J. Nishiyama for the statistical analysis. The cost of publishing this paper was defrayed in part by the payment of page charges. Under postal regulations, this paper therefore must be hereby marked advertisement solely to indicate this fact.
In western Canada, there is considerable producer interest in growing upright beans in rows 0.15 to $0.25 \mathrm{~m}$ apart to reduce equipment and manpower costs. However, anticipated gains in yield might be offset by a higher risk of white mold because of reduced air flow through the canopy. Under conditions favorable for diseases, the incidence of white mold was low in the open canopy of the upright navy bean line LRS92-1 in rows as narrow as $0.3 \mathrm{~m}$ (Saindon et al., 1993a). Park (1993) showed that whitemold incidence and disease index increased in upright and bush bean canopies as row width was narrowed. Several experimental bean lines with different upright growth habits have been developed, but their relative ability to avoid white mold at various densities in narrow row plantings has not been tested. The objectives of this study were to compare the architectural disease avoidance and agronomic attributes of four upright bean lines established in $0.23-\mathrm{m}$ rows in a field artificially infested with Sclerotinia sclerotiorum and to determine whether yields of upright beans grown in 0.23 -m rows under conditions favorable for white mold increase with higher planting density.

\section{Materials and Methods}

The experiment was conducted during 1990-93 at the Agriculture and Agri-Food Canada Research Centre at Lethbridge, Alberta, on a Typic Boroll soil. Two upright bean lines, LRS92-1 (navy, IIa, Lethbridge Research Centre, AB) and D84071 (navy, IIa, Rogers NK Seed Co., Idaho); two upright bean cultivars, ISB82865 (dark red kidney, Ia, Idaho Seed Bean Co., Idaho) and UI906 (black, IIa, Univ. of Idaho); and the viny bean cultivar U136 (red Mexican, IIIa, Univ. of Idaho), used as a susceptible control, were established at four planting densities $\left(25,35,50\right.$, and 60 plants $\left./ \mathrm{m}^{2}\right)$. Plots were overseeded during the third week of May and, where needed, densities were adjusted by thinning 3 weeks after seedling emergence. For each plot, plants were counted and the actual plant densities calculated. Emergence was erratic at times, which resulted in some plots with plant densities lower than those intended. 
Plots consisted of six 6-m-long rows with 0.23 -m spacing between rows and plots. The test was conducted as a $5 \times 4$ factorial and the 20 treatments were arranged in a randomized complete block design with three (1990) or four (1991-93) replications.

The experimental area was artificially infested with sclerotia of $S$. sclerotiorum collected from sunflower heads. Sclerotia were buried at a depth of 0.01 to $0.02 \mathrm{~m}$ in three of the five inter-row spaces (30 sclerotia/m) in 1990 and 1991, whereas, in 1992 and 1993, they were broadcast $\left(100 \mathrm{sclerotia} / \mathrm{m}^{2}\right)$ and incorporated with a field cultivator followed by a spiketooth harrow before seeding. The infection of plants was primarily by ascospore discharge and subsequent colonization of blossoms. Herbicides and fertilizers were applied yearly at recommended rates. The experimental area was sprinkler-irrigated regularly during July and August to maintain a moist soil surface under the canopy.

In September, just before harvest, the total number of plants, the number of plants with white-mold symptoms, and the number of plants killed by the pathogen were counted in the middle two ( 1990) or four ( 199 1-93) rows. From these data, the percentage of infected and dead plants was determined and a disease severity index (1 to 4 ) was calculated as follows:

where $\mathrm{NH}=$ number of healthy plants, $\mathrm{N1}=$ number of plants with one infected branch, $\mathrm{N} 2$ = number of plants with two or more infected branches, ND = number of dead plants, and $\mathrm{N}=$ total number of plants. Agronomic attributes such as vine length $(\mathrm{cm}$, average of three to five random plants), lodging (classes $1=$ erect to $5=$ flat) and maturity (days to maturity or classes $1=$ early to 3 $=$ late) were also estimated. At maturity (except for 1992 when an August snowfall prematurely terminated the experiment), plants were harvested and threshed, and yield $\left(\mathrm{kg} \cdot \mathrm{ha}^{-1}\right)$ and seed weight (mg) were measured. Seed lots were also examined for contamination by sclerotia and the number of sclerotia $/ \mathrm{kg}$ of seeds determined.

Analyses of covariance (Bliss 1967, 1970) were carried out on the disease and agronomic data for each year. Effects due to replicates and lines were included in the statistical model as well as terms for linear and quadratic regressions involving the independent variable, actual plant density, and their interaction with lines. A priori contrasts were calculated to compare the upright lines and the viny control as well as their regressions. Logarithmic transformations were applied to the percentages of infected and dead plants, the seed weight, and the number of sclerotia per kilogram of seeds, as it was evident that the treatment means and standard deviations were not independent. To simplify interpretation, geometric (backtransformed) means are reported. Analyses of covariance were also carried out across the years by adding effects due to years, replicates within years, and the interactions of year with line and planting density. The effect of year was considered to be fixed and, when the variances were heterogeneous for the years, weighted analyses were performed with weights as the inverse of the estimated variances for the years. The statistical analyses were performed using SAS (SAS Institute, Cary, N.C.).

\section{Results}

From the analyses of covariance across years, line $\mathrm{x}$ year interactions were evident $(P<0.01)$ for all variables measured, and polynomial regressions involving densities were not consistent for the years. Within years, effects due to lines were generally highly significant $(P<0.001)$ for all disease and agronomic attributes. The effects of planting density were most evident on the percentages of infected and dead plants and yield, and a line $\mathrm{x}$ density interaction was also present $(P<0.05)$ in some years for these variables. Therefore, results are presented for each year separately.

Effects of lines. Field conditions were conducive to the establishment of white mold with disease incidence on the susceptible 'UI36' control ranging from moderate (10.9\%) in 1991 to high (>45.0\%) in 1990 and 1993 (Table 1). A priori contrasts from the analyses of variance revealed that, collectively, the four upright lines had fewer infected plants and dead plants and lower disease severity indices than UI36, indicating that the upright plant growth habit helped reduce the development of the disease. Significant $(P$ $<0.05)$ line $\times$ density interactions were present for these variables in 1992 and 1993, but the large effect due to lines $(\mathrm{P}<0.001)$ indicated that the differences between the upright lines and 'UI36' were similar across densities. There were large differences among the four upright beans for the percentages of infected and dead plants, disease severity index, and the number of sclerotia present in harvested seed. Of the upright lines, 'ISB82865' was least prone to white mold, whereas 'UI906' was most susceptible and, as expected, the seed lots of 'ISB82865' had the fewest sclerotia per kilogram of seeds, whereas 'UI906' had the most (Table 1).

It is not clear whether the high yields and seeds weights obtained in 1991 solely reflected the good growing conditions and

Table 1. Disease response of five common bean lines grown in 0.23-m rows in a field artificially infested with Sclerotinia sclerotiorum.

\begin{tabular}{|c|c|c|c|c|c|c|c|c|c|c|c|c|c|c|c|}
\hline \multirow[b]{2}{*}{ Line/contrast } & \multicolumn{4}{|c|}{ Infected $(\%)$} & \multicolumn{4}{|c|}{ Dead $(\%)$} & \multicolumn{4}{|c|}{ Disease severity index $x^{2}(1-4)$} & \multicolumn{3}{|c|}{ Sclerotia/kg seeds (no.) } \\
\hline & 1990 & 1991 & 1992 & 1993 & 1990 & 1991 & 1992 & 1993 & 1990 & 1991 & 1992 & 1993 & 1990 & 1991 & 1993 \\
\hline$\overline{\text { LRS92-1 (1) }}$ & $23.3^{y}$ & 0.4 & 0.2 & 11.6 & $10.8^{y}$ & 0.3 & 0.0 & 2.0 & 1.59 & 1.01 & 1.02 & 1.28 & $82^{y}$ & 0 & 151 \\
\hline D84071 (2) & 29.9 & 0.1 & 0.6 & 4.6 & 15.5 & 0.0 & 0.0 & 1.1 & 1.81 & 1.00 & 1.05 & 1.16 & 92 & 0 & 50 \\
\hline UI906 (3) & 49.6 & 1.0 & 0.1 & 15.7 & 31.1 & 1.0 & 0.0 & 5.0 & 2.29 & 1.04 & 0.96 & 1.48 & 288 & 0 & 236 \\
\hline ISB82865(4) & 0.9 & 0.1 & 0.3 & 2.8 & 0.4 & 0.1 & 0.0 & 0.6 & 1.03 & 1.00 & 1.02 & 1.07 & 13 & 0 & 16 \\
\hline UI36 & 52.4 & 10.9 & 27.3 & 45.1 & 43.9 & 6.7 & 15.8 & 19.4 & 2.66 & 1.33 & 1.81 & 2.08 & 444 & 0 & 383 \\
\hline $\mathrm{SE}$ & $0.0770^{\mathrm{x}}$ & 0.0501 & 0.0554 & 0.0824 & $0.0769^{x}$ & 0.0409 & 0.0568 & 0.0795 & 0.14 & 0.03 & 0.05 & 0.07 & $0.118^{x}$ & 0.1 & 0.1073 \\
\hline $\mathrm{df}$ & 48 & 71 & 70 & 71 & 48 & 70 & 11 & 71 & 48 & 70 & 70 & 71 & 48 & -- & 71 \\
\hline 1 vs. 2 & NS & $\dagger$ & $*$ & $* *$ & NS & NS & --- & NS & NS & NS & NS & NS & NS & --- & $* *$ \\
\hline 1,2 vs. 3 & $* *$ & $* * *$ & NS & $* *$ & $* * *$ & $* * *$ & --- & $* * *$ & $* * *$ & NS & NS & $*$ & $* * *$ & -- & $* *$ \\
\hline $1,2,3$ vs. 4 & $* * *$ & $*$ & NS & $* * *$ & $* * *$ & $*$ & $\cdots$ & $* * *$ & NS & NS & NS & $* *$ & $* * *$ & --- & $* * *$ \\
\hline $1,2,3,4$ vs. UI36 & $* * *$ & $* * *$ & $* * *$ & $* * *$ & $* * *$ & $* * *$ & -- & $* * *$ & $* * *$ & $* * *$ & $* * *$ & $* * *$ & $* * *$ & --- & $* * *$ \\
\hline
\end{tabular}

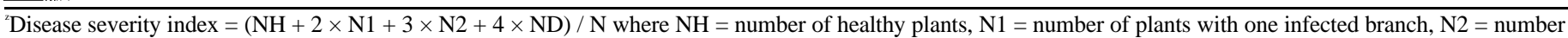
of plants with two or more infected branches, $\mathrm{ND}=$ number of dead plants, and $\mathrm{N}=$ total number of plants.

${ }^{y}$ Geometric means following a $\log _{10}(x+1)$ transformation for percentages of infected and dead plants and a log 10 transformation for number of sclerotia. ${ }^{\mathrm{x}}$ Standard errors of a mean in $\log _{10}$ units.

$\mathrm{NS}, \dagger, *, * *, * * *$ Contrasts are nonsignificant or significant at $P<0.1,0.05,0.01$, or 0.001 , respectively. 
Table 2. Yield and seed weight of five common bean lines grown in 0.23-m rows in a field artificially infested with Sclerotinia sclerotiorum.

\begin{tabular}{|c|c|c|c|c|c|c|}
\hline \multirow[b]{2}{*}{ Line/contrast } & \multicolumn{3}{|c|}{ Yield $\left(\mathrm{kg} \cdot \mathrm{ha}^{-1}\right)$} & \multicolumn{3}{|c|}{ Seed wt (mg) } \\
\hline & 1990 & 1991 & 1993 & 1990 & 1991 & 1992 \\
\hline$\overline{\text { LRS92-1(1) }}$ & 1381 & 2849 & 787 & $183^{2}$ & 211 & 111 \\
\hline D84071 (2) & 1427 & 2462 . & 952 & 159 & 171 & 121 \\
\hline UI906 (3) & 1454 & 2798 & 902 & 148 & 174 & 101 \\
\hline ISB82865(4) & 1716 & 1736 & 1571 & 553 & 522 & 462 \\
\hline UI36 & 1422 & 4344 & 994 & 290 & 335 & 198 \\
\hline SE & 87 & 135 & 43 & $0.005^{y}$ & 0.0056 & 0.0038 \\
\hline $\mathrm{df}$ & 49 & 71 & 70 & 49 & 71 & 71 \\
\hline 1 vs. 2 & NS & $*$ & $* *$ & $* * *$ & $* * *$ & $* * *$ \\
\hline 1,2 vs. 3 & NS & NS & NS & $* * *$ & $* * *$ & $* * *$ \\
\hline $1,2,3$ vs. 4 & * * * & $* *$ & $* * *$ & $* * *$ & $* * *$ & $* * *$ \\
\hline $1,2,3,4$ vs. UI36 & NS & $* * *$ & NS & $* * *$ & $* * *$ & $* * *$ \\
\hline
\end{tabular}

${ }^{2}$ Geometric means following a $\log _{10}(\mathrm{x})$ transformation.

${ }^{y}$ Standard errors of a mean in $\log _{10}$ units.

Ns,$* * * * * *$ Contrasts are nonsignificant or significant at $P<0.5,0.01$, or 0.001 , respectively.

Table 3. Agronomic characteristics of five common bean lines grown in $0.23-\mathrm{m}$ rows in a field artificially infested with Sclerotinia sclerotiorum.

\begin{tabular}{|c|c|c|c|c|c|c|}
\hline \multirow[b]{2}{*}{ Line/contrast } & \multicolumn{2}{|c|}{ Vine length $(\mathrm{cm})$} & \multicolumn{2}{|c|}{$\operatorname{Lodging}^{2}(1-5)$} & \multicolumn{2}{|c|}{ Maturity $^{y}$} \\
\hline & 1990 & 1993 & 1990 & 1993 & 1991 & 1993 \\
\hline LRS92-1 (1) & 55.7 & 34.4 & 1.43 & 1.99 & 105.1 & 2.57 \\
\hline D84071 (2) & 35.4 & 26.9 & 1.57 & 2.35 & 102.1 & 1.60 \\
\hline UI906 (3) & 48.4 & 29.4 & 2.02 & 2.04 & 103.6 & 2.83 \\
\hline ISB82865(4) & 29.7 & 31.9 & 0.95 & 2.01 & 102.0 & 1.05 \\
\hline UI36 & 75.1 & 55.9 & 4.10 & 3.54 & 103.3 & 2.14 \\
\hline $\mathrm{SE}$ & 3.7 & 1.9 & 0.24 & 0.12 & 0.3 & 0.13 \\
\hline $\mathrm{df}$ & 49 & 71 & 49 & 71 & 70 & 71 \\
\hline 1 vs. 2 & $* * *$ & $* *$ & NS & $* *$ & $* * *$ & $* * *$ \\
\hline 1,2 vs. 3 & NS & NS & $*$ & NS & NS & $* * *$ \\
\hline $1,2,3$ vs. 4 & $* * *$ & NS & $* *$ & NS & $* * *$ & $* * *$ \\
\hline $1,2,3,4$ vs. UI36 & $* * *$ & $* * *$ & $* * *$ & $* * *$ & NS & NS \\
\hline
\end{tabular}

Lodging is expressed on a relative scale ranging from 1 (up) to 5 (flat).

'Maturity is expressed as number of days after planting in 1991 and on a relative scale ranging from 1 (early) to 3 (late) in 1993.

Ns,$* * * * *$ Contrasts are nonsignificant or significant at $P<0.5,0.01$, or 0.001 , respectively.

low disease incidence occurring that year or were the result of other undetermined factors. The very high incidence of white mold in 1990 contributed to yields that were $42 \%$ lower overall and seeds that were $8 \%$ lighterin weight than those obtained in 1991 (Table 2). In 1993, poor growing conditions and a relatively high incidence of white mold contributed jointly to the very low yields and seed weights obtained. Yield differences among the upright lines were small in 1990 but considerable in 1991 and 1993. Of the upright lines, 'ISB82865' produced the most consistent yield over the. 3 years.

As expected, the four upright beans had shorter vine lengths and lodged less than the viny control (Table 3 ). There were generally large differences among the upright lines for vine length and lodging. LRS92-1 was the tallest upright line in the trial, but it did not lodge more than the other upright lines. All lines tested were within a relatively narrow range of maturity.

Effects of planting densities. Planting density influenced the development of white mold except in 1990 (Fig. 1). In 1993, the percentage of infected plants increased with planting density $(P<$ $0.01)$, when all lines were considered and $(P<0.05)$ when only the uprights were included. The percentage of infected plants of 'U136' appeared to decrease in 1990 and 1991 and increase in 1992 and 1993 with higher planting densities, but these responses were not significant $(P>0.05)$. In 1990 and 1993, the responses of the upright lines were consistent with planting densities, whereas there was a line $\times$ planting density interaction $(P<0.01)$ in 1991 and 1992. The percentages of infected plants also increased with planting density in 1991 for 'UI906' $(P<0.01)$ and in 1992 for 'ISB82865' and D84071 $(P<0.01)$. Of the upright lines, LRS921 was the least affected by planting density. Patterns of response similar to those presented for the percentage of infected plants were observed for the percentage of dead plants and disease severity indices (data not shown).

Yields of all upright entries increased linearly with increases in planting density in $1990(P<0.01)$ and $1991(P<0.10)$ (Fig. 2). In 1993, a curvilinear relationship between yield and planting density was observed among the upright lines, but the magnitude of the response was not the same for all the lines. Indeed, yields of the upright lines increased at a decreasing rate up to about 40 plants $/ \mathrm{m}^{2}$, above which yields decreased, whereas yields of ' $\mathrm{U} 136$ ' appeared to increase slowly but steadily up to 50 plants $/ \mathrm{m}^{2}$, above which yields remained almost unchanged. Changes in planting density had no effect on seed size, lodging scores, vine length, or crop maturity. 


\section{Discussion}

The relatively low disease levels of the upright bean lines demonstrate that white-mold development can be reduced in the close canopies produced by beans grown in $0.23-\mathrm{m}$ rows. This is consistent with other reports indicating that white-mold incidence and severity are not exacerbated by growing upright beans in 0.6m (Coyne et al., 1974) and 0.3-m (Park, 1993; Saindon et al., 1993a) rows. Our results also suggest that the erect growth habit of the upright lines is a reliable means for controlling white mold in 0.23 -m row systems.

The relatively short stature and good lodging resistance of the upright lines contrasted with the viny, prostrate growth habit of 'U136'. Although the short and sturdy upright lines generally produced erect canopies that were less conducive to white mold development, there were still large differences among the upright lines for disease levels in 2 of the 4 years and the magnitude of these differences was affected by the planting density. The determinate cultivar ISB82865 was almost disease-free in all 4 years. This line's erect growth habit, large leaf size, small leaf number, phyllotaxy, and possible innate physiological resistance all contributed to the low white-mold incidence. On the other hand, UI906 had moderate (1993) and high (1990) disease incidence despite its upright short vined (Myers et al., 1991) growth habit. The canopy structure of 'UI906' comprised many branches that were closely spaced in the upper two thirds of the main stem in contrast with the other upright lines that featured a strong main stem with a few or no branches. The different architecture of 'UI906', along with the frequent irrigation regime, may have produced dense growth in the upper part of the canopy and, thus, may have created an environment favorable for white mold. Park (1993) speculated that narrow canopy, higher flowering nodes, and fewer branches in the upright plants might contribute to white-mold avoidance.

The significance of line $\mathrm{x}$ year interactions was largely due to

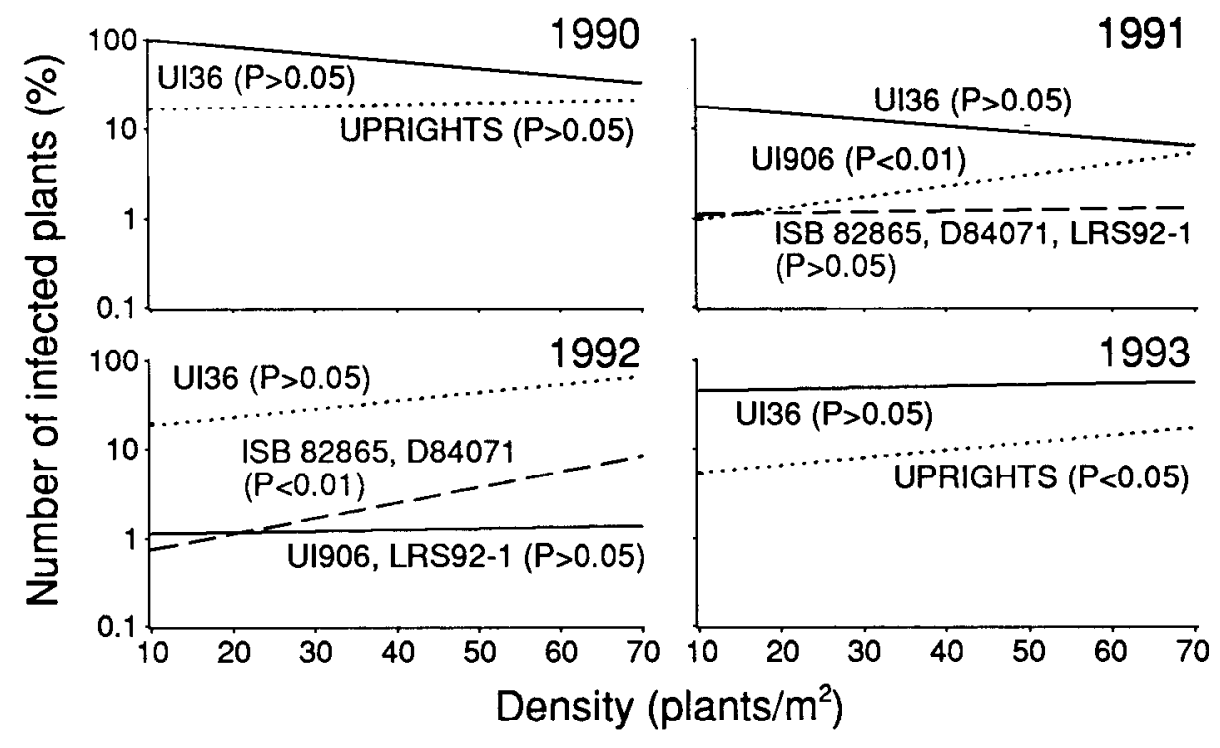

Fig. 1. Relationship between the $\log _{10}$ (percentage of infected plants +1$)$ and the actual planting density for viny control and upright bean lines grown in 0.23 -m rows in a field artificially infested with Sclerotinia sclerotiorum.

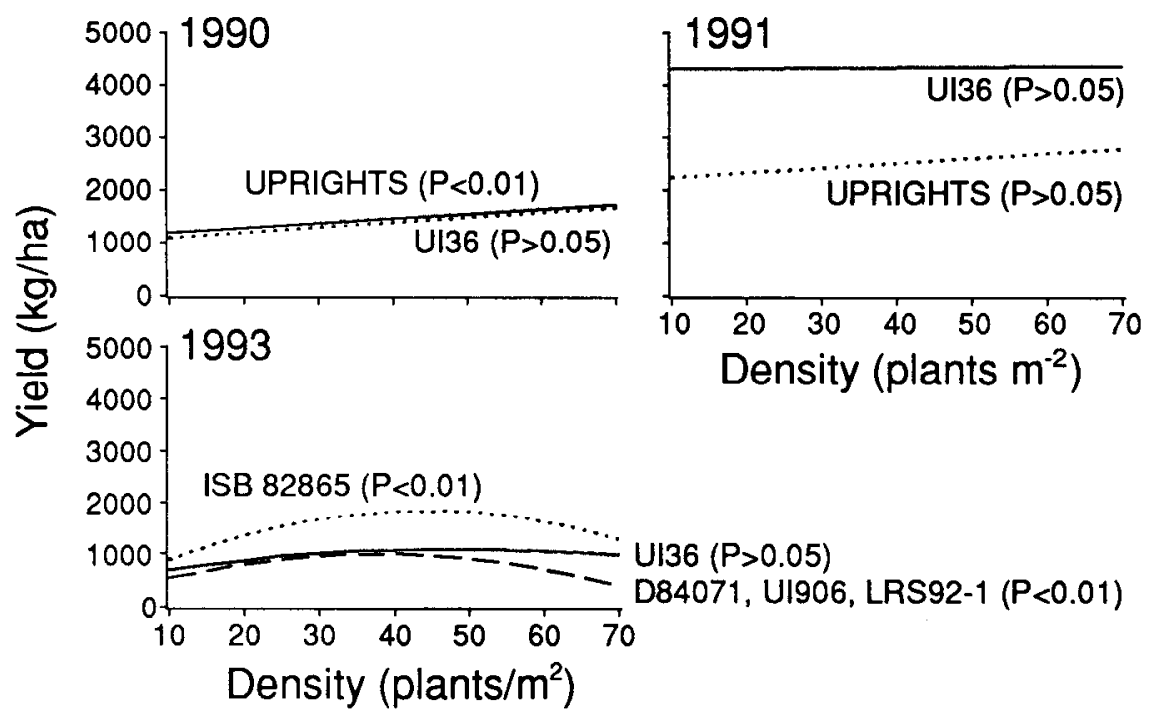

Fig. 2. Relationship between yield and the actual planting density for viny control and upright bean lines grown in 0.23-m rows in a field artifically infested with Sclerorinia sclerotiorum. 
the stability across years of the yields and seed weights of 'ISB82865', which was due to its low levels of disease incidence and severity. The relative yields and seed weights of the other upright lines were greatly reduced in 1990 and 1993 when white mold incidence was high or moderate. The line $\times$ year interactions among the upright lines other than ISB82865 for yields and seed weights were not large, indicating that these lines responded more or less similarly to environmental conditions, including those that favor the development of white mold.

The results of the planting density experiment generally support the hypothesis that upright beans can be grown at planting densities higher than those currently recommended without unduly increasing the risk for a white-mold outbreak. The upright lines had much less white-mold incidence than the susceptible control at all planting densities. The disease incidence increased in all the upright lines (1993), 'UI906' (1991), and 'ISB82865' and D84071 (1992) with increases in planting density, but rarely exceeded the moderate level. Furthermore, the highest level of infection in the upright lines occurred at a planting density greater than 45 plants $/ \mathrm{m}^{2}$, a planting density that current seed cost makes unattractive.

There was a yield advantage to growing upright beans in narrow rows at planting densities higher than those recommended for viny beans in wide rows. The $10 \%$ to $20 \%$ yield differences measured between 20 and 60 plants $/ \mathrm{m}^{2}$ are consistent with the results of previous studies (Mack, 1983; Redden et al., 1987; Tripathi and Singh, 1986) conducted in the absence of white mold. The decreasing yields of the upright lines at high planting densities in 1993 were associated with increases in disease incidence, but this relationship was not apparent in 1990 and 1991.

It appears that upright beans can be grown in $0.23-\mathrm{cm}$ rows without unduly increasing the risks for white mold. However, upright lines are not all equal in their ability to escape white mold, and choosing the most appropriate cultivar will be an important crop management decision. Yield advantages associated with growing upright beans at planting densities higher than those currently recommended makes bean production in narrow rows attractive. The choice of the most appropriate plant population for upright beans largely depends on the cost of seed.

\section{Literature Cited}

Bliss, C.I. 1967. Statistics in biology. vol. 1. McGraw-Hill, Toronto. Bliss, C.I. 1970. Statistics in biology. vol. 2. McGraw-Hill, Toronto. Coyne, D.P., J.R. Steadman, and F.N. Anderson. 1974. Effect of modified plant architecture of great northern dry bean varieties (Phaseolus vulgaris) on white mold severity, and components of yield. Plant Dis. Rpt. 58:379-382.

Field, R.J. and S. Nkumbula. 1986. Green beans (Phaseolus vulgaris Cv. Gallatin 50): effects of plant population density on yield and quality. New Zealand J. Expt. Agr. 14:435-442.

Huang, H.C., M.J. Kokko, and L.M. Phillippe. 1988. White mold of dry bean (Phaseolus vulgaris L.) in southern Alberta, 1983-87. Can. Plant Dis. Surv. 68: 11-13.

Mack, H.J. 1983. Fertilizer and plant density effects on yield performance and leaf nutrient concentration of bush snap beans. J. Amer. Soc. Hort. Sci. 108:574-578.

Mack, H.J. and G.W. Varseveld. 1982. Response of bush snap beans (Phuseolus vulgaris L.) to irrigation and plant density. J. Amer. Soc. Hort. Sci. 107:286-290.

Mauk, C.S., P.J. Breen, and H.J. Mack. 1983. Yield response of major pod-bearing nodes in bush snap beans to irrigation and plant population. J. Amer. Soc. Hort. Sci. 108:935-939.

Myers, J.R., R.E. Hayes, and J.J. Kolar. 1991. Registration of 'UI 906' black bean. Crop Sci. 3 1: 1710.

Park, S.J. 1993. Response of bush and upright plant type selections to white mold and seed yield of common beans grown in various row widths in southern Ontario. Can. J. Plant Sci. 73:265-272.

Redden,R.J., T. Usher, D. Younger, R. Mayer, B. Hall, A. Fernandes, and D. Kirton. 1987. Response of navy beans to row width and plant density in Queensland. Austral. J. Expt. Agr. 27:455-463.

Saindon, G., H.C. Huang, G.C. Kozub, H.-H. Mündel, and G.A. Kemp. 1993a. Incidence of white mold and yield of upright beans grown in different planting patterns. J. Phytopathol. 137: 118-1 24.

Saindon, G., H.C. Huang, H.-H. Mtindel, and G.A. Kemp. 1993b. Registration of an upright common bean germplasm line LRS92-1. Crop Sci. 33:353.

Shibles, R.M. and CR. Weber. 1966. Interception of solar radiation and dry matter production by various planting patterns. Crop Sci. 6:55-59. Tripathi, S.S. and P.P. Singh. 1986. The association of planting density and plant type in French bean (Phaseolus vulgaris). Expt. Agr. 22:427-429.

Wahab, M.N.J., D.H. Dabbs, and R.J. Baker. 1986. Effects of planting density and design on pod yield of bush snap bean (Phaseolus vulgaris L.). Can. J. Plant Sci. 66:669-675. 